DOI

\title{
ВИКОРИСТАННЯ НАРАДИ ЯК ФОРМИ КОЛЕКТИВНОГО СПІЛКУВАННЯ ДЛЯ ЯКІСНОГО ПЛАНУВАННЯ РОБОТИ КАФЕДРИ НЕВРОЛОГІЇ ОДЕСЬКОГО НАЦІОНАЛЬНОГО МЕДИЧНОГО УНІВЕРСИТЕТУ НА СУЧАСНОМУ ЕТАПІ
}

\author{
Т. М. Муратова, В. В. Добровольський
}

Одеський національний медичний університет

\section{USING THE MEETING AS A FORM OF COLLECTIVE COMMUNICATION FOR QUALITY WORK PLANNING OF NEUROLOGY DEPARTMENT OF ODESA NATIONAL MEDICAL UNIVERSITY AT THE PRESENT STAGE}

\author{
T. M. Muratova, V. V. Dobrovolskyi \\ Odesa National Medical University
}

\begin{abstract}
У статті представлений аналіз однієї з найважливіших форм спілкування в колективі - наради, яка виходить на перший план в організації роботи по керівництву будь-якого колективу. Наради проводяться не тільки при обговоренні та вирішенні проблемних питань. Керівник призначає наради при проведенні підсумків на певному етапі роботи колективу кафедри. Саме тому на нараді керівником ставляться завдання, розглядаються умови їх виконання (хто, що, коли), складається план роботи колективу на певний період. Нарада на сучасному етапі реформування медицини $є$ важливою формою спілкування в колективі. Вона буде ефективною, якщо дотримуватися принципів і правил спілкування.
\end{abstract}

The article presents an analysis of one of the most important forms of communication in the team - a meeting, that comes to the fore in the work to lead any team. Meeting is held not only in the discussion and resolution of issues. Leader appoints the meeting during the outcomes at a certain stage of the department staff. That is why the meeting leader seeks considered conditions for their implementation (who, what, when), the plan of the team for a certain period. Meeting at the present stage of reform of medicine is an important form of communication in the team. It will be effective if you follow the principles and rules of communication.

Вступ. Одним з найефективніших засобів обговорення й прийняття рішення щодо важливих проблем навчальної, виховної та лікувальної роботи на кафедрі неврології Одеського національного медичного університету є нарада зі співробітниками. Така форма спілкування дає можливість спільно аналізувати важливі питання, приймати важливі рішення керівництву, а співробітникам вільно висловлювати свої думки та вносити пропозиції. Наради завжди досить широко застосовувались на кафедрі, але, в скрутні часи для держави, в період реформування виникає багато питань, які необхідно вирішувати керівництву спільно з усіма співробітниками кафедри, а деколи і зі студентським активом [1].

Основна частина. Завдяки нарадам, які проводяться на кафедрі систематично, учасники обмінюються думками, обговорюють проблеми і спільними зусиллями досягають певних висновків.

() Т. М. Муратова, В. В. Добровольський
Ефект від таких нарад значний, тому що допомагає приймати виважені рішення керівництву кафедри, деканату і ректорату університету.

Оптимальна кількість учасників наради як однієї з форм обговорення - 10-12 чоловік. Якщо людей менше, то й користі в неї буде менше, тому що зменшується кількість різних поглядів на проблему. Якщо кількість осіб перевищує 16-10 чоловік, то, як правило, не всі зможуть взяти участь в обговоренні питання [2].

Наради на кафедрі готуються заздалегідь. Результати наради залежать від головуючого, який керує нею. При вмілому керівництві на нараді можливо досягти вагомих результатів. Керівник наради зосереджує свою увагу й зусилля на тому, щоб постійно стежити за ходом обговорення, підбирати слушні запитання, систематизувати різні погляди, вчасно робити висновки. Керівництву важливо поєднувати бажання дискутувати й вміло керувати нарадою. Завдання керівника полягає в тому, щоб координувати роботу підлеглих, постійно трима- 
ти в полі зору всі справи, постійно думати про колектив, як одне ціле, та завдання, які перед ним стоять. Керівнику бажано не ставитися зверхньо до учасників наради, не допускати недооцінки їх, важливо прислухатися до висловлювань кожно- го, тому що ефективність наради якраз й полягає в тому, щоб виробити спільну думку, яка нерідко важить набагато більше, ніж сума окремих думок співробітників кафедри.

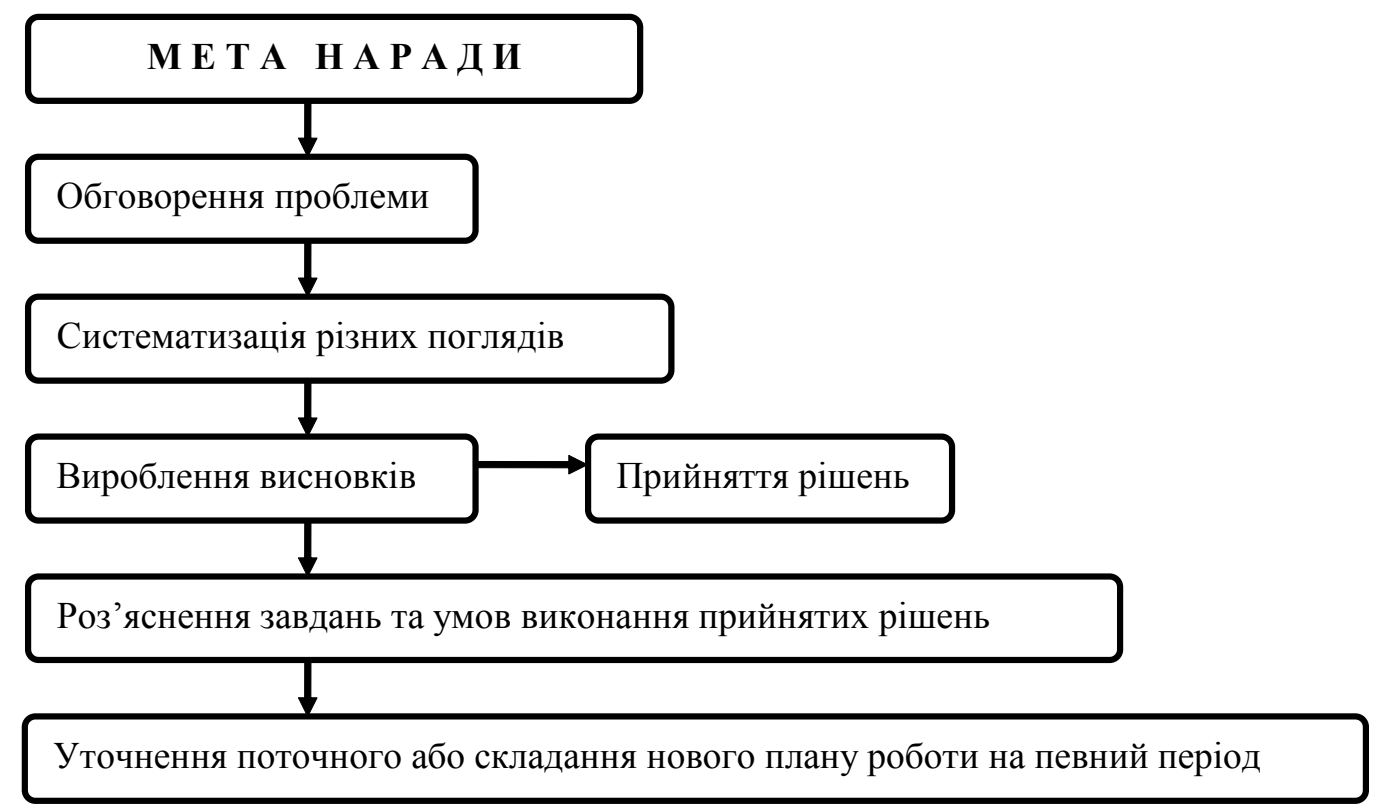

Дуже важливо також однаково ставитися до всіх співробітників - учасників наради. Доброзичлива атмосфера необхідна для вільного обміну думками. Керівнику слід бути тактовним і витриманим [3]. Часто буває, що під час обговорення одні починають нервувати, а інші без зупинки говорити, не даючи нікому сказати слово. Нарада може перетворитися в пусту “балаканину”, тому керівник втручається i спрямовує обговорення в належне русло. При цьому він мусить бути тактовним, щоб його втручання сприймалося правильно. Завдання керівника полягає не у виголошенні промови чи доповіді. Він відкриває нараду, в короткому вступному слові характеризує проблему, яку треба обговорити. Під час наради керівник за допомогою певних запитань заохочує присутніх до дискусії, систематизує та пе- ріодично робить висновки, ставить на обговорення нові питання й, нарешті, підводить підсумки.

Висновки. Таким чином, головна цінність нарад у тому, що на них підводяться підсумки важливих питань, ставляться завдання, визначаються умови їх виконання. Така форма спілкування зі співробітниками, як нарада, виходить на перший план в організації роботи по керівництву будьякого колективу. Наради проводяться не тільки при обговоренні та вирішенні проблемних питань. Керівник призначає наради при проведенні підсумків на певному етапі роботи колективу кафедри. Саме тому на нараді керівником ставляться завдання, розглядаються умови їх виконання (хто, що, коли), на основі яких складається план роботи колективу на певний період.

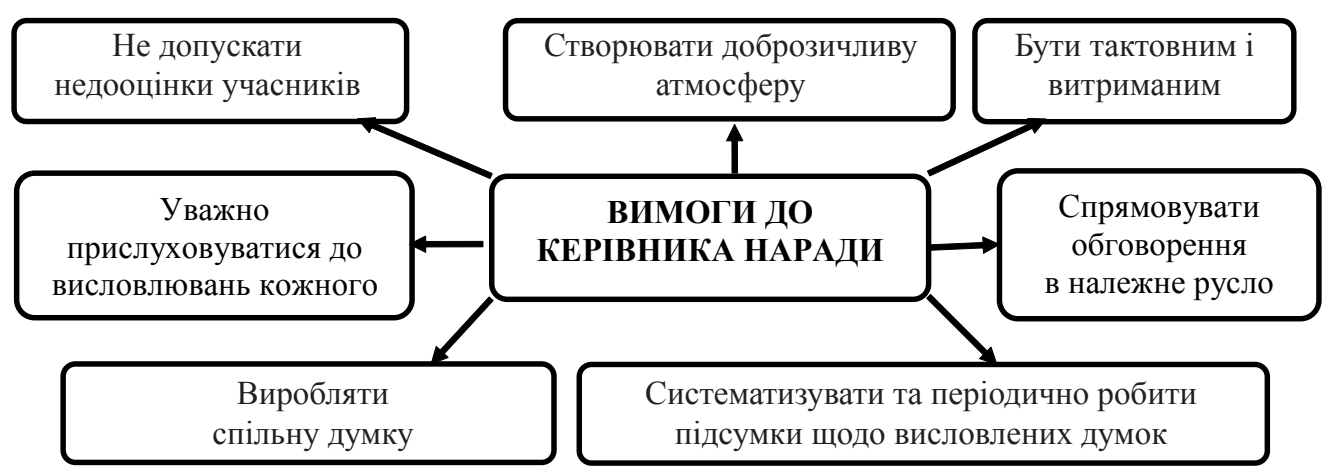


Нарада на сучасному етапі реформування медицини є важливою формою спілкування в колективі. Вона буде ефективною, якщо дотримуватися принципів і правил спілкування. Така форма роботи на кафедрі неврології і в Одеському на-

\section{Список літератури}

1. Логуш Л. Г. Перспективні напрями розвитку медичної освіти в Україні / Л. Г. Логуш // Педагогічний процес: теорія і практика. - 2013. - Вип. 3. - С. 117-123.

2. Ягупов В. В. Педагогіка : навч. посіб. / В. В. Ягупов. - К. : Либідь, 2002. - 560 с. ціональному медичному університеті стала одним із напрямків демократизації навчального процесу і запорукою підвищення якості підготовки лікарів на сучасному етапі реформування медицини.

3. Ушинский К. Д. Человек как предмет воспитания: опыт педагогической антропологии / К. Д. Ушинский // Педагогические сочинения. - М. : Педагогика, 1990. T. $6 .-528$ с. 